\title{
OPTIMIZATION AND IMPROVEMENT OF TEST PROCESSES ON A PRODUCTION LINE
}

\author{
Erika SUJOVÁ, Helena ČIERNA \\ Technical University in Zvolen
}

\begin{abstract}
:
The paper deals with increasing processes efficiency at a production line of cylinder heads of engines in a production company operating in the automotive industry. The goal is to achieve improvement and optimization of test processes on a production line. It analyzes options for improving capacity, availability and productivity of processes of an output test by using modern technology available on the market. We have focused on analysis of operation times before and after optimization of test processes at specific production sections. By analyzing measured results we have determined differences in time before and after improvement of the process. We have determined a coefficient of efficiency OEE and by comparing outputs we have confirmed real improvement of the process of the output test of cylinder heads.
\end{abstract}

Key words: test processes improvement, Overall Equipment Efficiency - OEE, output test

\section{INTRODUCTION}

Efficiency of the process generally determines efficiency of input resources and benefits that they bring. It is a proportion of the output and input of a given activity or a system. From a management of company point of view, it determines a proportion of quality of final products and amount of resources input into the production process. It is the, so called, use of resources, which can reach maximum volume of production and quality of products and reduction of human work in production. Only healthy companies have a chance to succeed in this highly competitive environment. Customers expect companies to deliver their orders in the shortest time, at the lowest price and with the highest quality, which can be achieved only by increasing productivity and efficiency of a company [3, 6, 7].

The paper deals with improvement and optimization of test processes on a production line of cylinder heads of engines in a production company. It discusses the subject of increasing efficiency of test processes at a production line of cylinder heads of engines in a production company operating in the automotive industry. Production of castings of heads of cylinders belongs to high-tech components with complex technological parts. Customers'demands and demands for high quality of products in the above-mentioned industry are only increasing. The goals of increased competition are decreasing production costs, which are directly projected on the price of the final product. After analysis of the production process, we suggest a new arrangement of the production line for the final test of products by implementing a new measuring device. Our suggestion will simplify the entire process, manipulation of castings; will simplify manipulation of the process and will add financial savings.
The research is part of a solution of a project subsidised by the KEGA no. 011TU Z-4/2017 project "Integration of progressive information technologies and soft-skills in education programs focusing on management of production processes".

\section{OVERALL EQUIPMENT EFFICIENCY (OEE)}

Measuring overall equipment efficiency has an irreplaceable role when evaluating efficiency of production equipment, production lines, technological results, or of entire production companies. Overall Equipment Effectiveness (OEE) is a recognized coefficient, which is a comparable parameter around the world. OEE takes into consideration availability, equipment performance and produced quality. It can be expressed in percentages as part of effective use of equipment in relation to time when equipment is available for product production [3].

OEE is a tool that evaluates overall efficiency of a production line calculated by adding three factors: availability, performance, quality. Overall equipment efficiency takes into consideration three parameters that describe a state of a production process, which are availability $(A)$, performance of equipment $(P)$ and produced quality $(Q)$ :

- availability (use) of equipment (A-vailability) - compares times when the equipment was in production and when it could be in production,

- performance of equipment (P-erformance) - compares actually produced amounts with amounts set by a norm,

- quality of production (Q-uality) - compares number of produced pieces of required quality with the final number of products. 
Calculation of the OEE coefficient is based on the following relationship:

$$
O E E=A \cdot P \cdot Q
$$

Final data portray clear and unbiased comparison between how each individual production equipment is utilized or not utilized. By monitoring efficiency, we can increase efficiency not only in jumps, but also systematically. It allows for optimization of production processes, increase in productivity of production processes, use of human resources and use of materials. Cost optimization and optimization of interval maintenance are also significant [2].

\section{DESCRIPTION OF CYLINDER HEADS OF ENGINES PRODUC- TION}

\section{Technological process of production}

The analyzed company predominantly produces castings of cylinder heads for various automotive producers. A cylinder head can be considered a fundamental part of each reliable engine. It has a difficult shape since it consists of numerous channels for cooling, for air intake and output of exhaust, and more. Cylinder heads are made by the gravitational casting method. The principle of gravitational casting is based on filling a form using gravity [1].

The technological process commences by selection of cores, preparation of the metal, casting into metal forms. Following is cleaning of separating planes and removal of sand, which creates cavities in the casting, sawing of technological fillings. The following heat process adds the casting structure and hardiness. Some of the final procedures include work with the CNC equipment - finishing centers. A very important final step of the production process of cylinder heads for engines is output testing [8].

\section{Characterization of the output test process}

Output testing is the final part of the production cycle. It is an operation or a group of operations that control a produced part - casting before packaging and shipment to the end customer. The test process checks on the casting whether is conforms to specified norms and production documentation as well as specific norms specified by the customer. These norms differ, depending on customer, automobile manufacturer [4].

Examples of specific norms are allowed errors, insufficiencies defined by a specific place, number of defects and more. In addition to a visual check, other important components of the casting need to be verified. These are for example:

- passability of the water core,

- presence of openings of a water core,

- dimensional accuracy of position of the burning area and opening that composes the exhaust and suction area,

- tightness of openings for the water and oil areas as well as other places that could possibly lose pressure and fluids that would render the engine dysfunctional,

- other inclusions need to also be checked, such as shavings from finishing, which could render the engine dysfunctional.

Operations of the output test process before improvement

1. Control of tightness of the water and oil areas. The main principle is to check the casting under water for visible loss of air in form of bubbles rising to the surface. The advantage of the method is accurate detection of the place of leak and technological possibility to remove this defect based on accurate localization and statistical occurrence in this specific area.

2. Checking for existing openings - the casting, on the burned side, a mold which in places of openings have pegs of various dimensions depending on the actual openings. This mold is freely placed on the casting and all pegs need to fall into openings.

3. Passability of openings of the water area is checked by the „needle“ test. Part of the oil core and core for a water pump are checked ", tape“ test. The needle test consists of checking openings of the water area by inserting a wire from flexible steel into all openings and directions of the water area.

4. During visual check a casting is checked for casting and surface errors, mechanical damage, outstanding impurity, check of air intake and outtake area, presence of all markings, that confirm specific checks and errors, which could affect performance [4].

\section{Operations of the output test process after improvement}

For tightness test of the water and oil areas we suggest automatic equipment, which works based on an air-air system. Specific amount of air is forced into the casting, which creates certain pressure. The pressure is continuously measured until it reaches approximately $15 \mathrm{~s}$. If there is no decrease in pressure, the casting is declared to be pressure tight. If there is decrease in pressure, there is a gap causing this loss of pressure and the casting is declared as not tight. The same process is repeated also for pressurizing other areas. Everything takes place in one equipment which moves the casting between sections, automatically on a precise trajectory placed in one appliance. After a successful completion of the tightness test, the results are indicated and the casting is marked with letters $W$ and $O$. The equipment also checks the area of the water area - Flow test.

Datalan a.s. invented and patented equipment for testing passability and presence of openings Light Thru. The unique project started with cooperation with Neman Slovak s.r.o. Light Thru equipment is used to test integrity of the water area of castings and other products, predominately of cylinder heads for the automotive industry. The equipment is capable of detecting broken integrity of a water lining, impenetrable cooling liquid, which renders the casting defective $=$ inconsistent part. Figure 1 portrays a principle of activity of the equipment by the passing channel (a) in case when there is debris in the channel (b). The equipment works on the principle of optical fibers, which send light into channels. The fibers also absorb reflected light and direct it to the measuring device. If the light from the channel is blocked by debris, which is in the channel (broken core, CNC splitting, dirt from the core, etc.), the light will reflect from the debris into the original measuring device of the optical fiber. a)

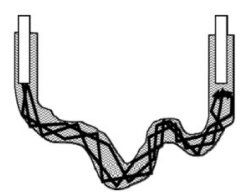

b)

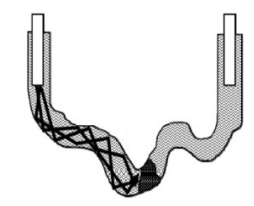

Fig. 1 Portrayal of a passable channel (a) and not passable channel (b)

Source: [5]. 
A device for checking presence of openings, that includes a camera, which will record the casting, is an additional device to the Light Thru system. Based on color distinction, black/white, it prepares an outline of the opening, which is compared to a mathematical model. By comparing the picture and a model we evaluate presence of openings and evaluate the correct shape of defined openings.

The individual measuring probe assemblies (Figure 2) are designed so that the paths between all designated pairs of the transmitting element - the receiver element - cover a sufficient number of channels to evaluate the product being inspected.

\section{RESULTS}

Results of evaluation of performance of the output test process before improvement

Pressurizing of the water area is usually selected as the first test. With this method of testing, after evaluating availability, performance and quality with the current cycles, we calculated, with the help of measured time, 157.2 pieces of castings per one work shift.

Pressurizing of the oil area is usually selected as the second test. This method of testing was after evaluating availability, performance and quality with current cycles, calculated, with the help of measured time, 227.5 pieces of casting per one work shit.

The output test is the final operation before packaging and shipping to the customer. This test checks presence of openings, visual check for defects, marking of previous tests. At the end of this visual "check-up" a marking will be put on the casting and it will be packed info packaging material specified by the customer. The table portrays aforementioned individual times of tests. We have determined performance of a process of 161.4 pieces of casting per work shift based on times received during tests and by using OEE [4].

Results of evaluation of performance of the output test process after improvement - after integration of testing activities in one production line

After integrating testing activities into one production line and implementation of a test of tightness, device for testing passability and presence of openings with the help of Light Thru, we measured cyclical times and have indicated measured time in Table 1 - the blue color indicates parallel operations.

From these times and taking into consideration OEE, we have expressed performance of the process as 336 pieces of castings as a change. We have not added into the cyclical time performance of a robot, test of the pressure device or test with Light Thru. These are in the "background" because these are taking place parallel to the tests of the casting.

\section{Evaluation of results of an integrated cell}

Results calculated in Table 1 are actual pieces only if ideal cyclical time is calculated from individual measurements. These values do not offer an accurate overall picture about expected volume. In terms of reality of these results, we have adjusted the values using coefficient of Overall Equipment Efficiency, OEE, the following way:

1. Availability $-10 \%$ is deducted from the total measured time of 480 minutes; this way we get number of pieces produce during $90 \%$ of working time.

2. Performance-during production, we need to be prepared for lower performance, which will be calculated from availability decreased by $9 \%$. The result is $91 \%$ availability.

3. Quality - is also a parameter decreasing total availability of the production line. It is calculated from performance decreased by $10 \%$. The result is $90 \%$.

In Table 2 we indicate the final value of the overall time that a test lasts per one casting for a process of internal test before improvement and after adjustment with coefficient OEE. The total time of the check per one casting is expressed from values of performance of the output test process before improvement [4].

Table 1 shows that the real number of products after calculation with OEE, which during one shift (480 minutes) go through an output test process on an improved production line with integrated processes, is 336 pieces. We can express from this the final time of duration of a test per one casting for an output test process after improvement, which is 1.43 minutes. Table 3 shows comparison of achieved results.

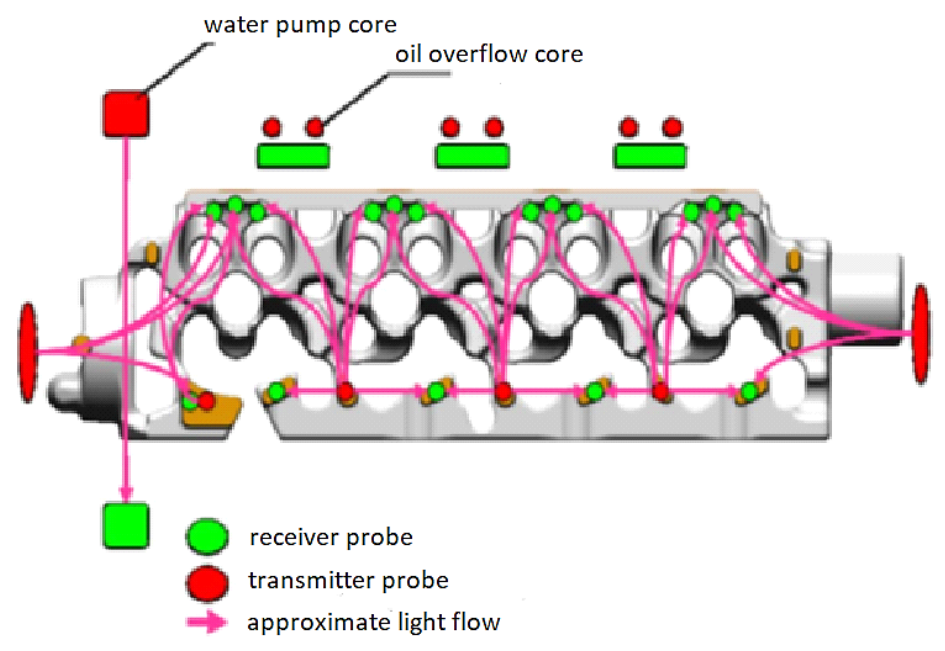

Fig. 2 Distribution of probes in the water core

Source: [5]. 
Table 1

Time stamp of a productions line after improvement

Product: Cylinder head

Workpleace: Output test, test of casting + pressurization, camera, light thru

\section{List of activities}

Placing of casting on the conveyer belt

Pressurizing of casting Koster

Camera test to determine presence of openings + light thru

Visual check of casting for possible defects

Cleaning mechanical sander

Cleaning by shinning

Production of one piece

Pieces per shift

Mechanical cleaning

Identifing by symbol

Placement into GTB

Final time of test

Total time of cycle (sec)

Total time of cycle (min) - CCC

Number of pieces in 60 minutes

Number of pieces per shift (480 minutes)

Availability $A=480 * 90 \% / C C C$

Performance $P=A * 91 \%$
Average time of activity (sec.)

2.4

74.0

70.0

14.7

17.1

17.5

3.8

2.3

5.2

56.3

63.0

1.1

57.1

456.9

411.2

374.2

Quality $Q=P^{*} 90 \%$

336.8

$\mathrm{OEE}=\mathrm{A}^{*} \mathrm{P}^{*} \mathrm{Q}$

$74 \%$

Real number of pieces per shift

Source: [4].

Table 2

Calculation of final value of total time of testing per one casting during the output test process before improvement

\begin{tabular}{lccc}
\hline Activity & Pressurization of water area & Pressurization of oil area & Visual output test \\
\hline Min/piece & 3.05 & 2.11 & 2.97 \\
$\Sigma$ & & 8.13 & \\
\hline
\end{tabular}

Source: [4].

Table 3

Comparison of achieved results

Total time of testing of one casting Total time of testing of one casting during during the output test process before the output test process after improvement improvement

$$
8.13 \mathrm{~min}
$$

Percentage by which the time of the output test process was decreased after improvement

$82.5 \%$

Source: [4].

\section{CONCLUSION}

The goal of the paper was to suggest improvement of efficiency of the output test process. Through integration of three test activities with automated technologies and a new measuring device, the output test became more effective by $82.5 \%$. Another advantage of the solution is increase in quality of tested activities. This advantage, which protects the customer, cannot be evaluated. It is very important, because customer trust and satisfaction is achieved by prevention before possible risk of shipping incompatible pieces. In no circumstances can we think only about increase of performance by expressing volume of tested casting, but also through unification and reliability of test activities. Finally, by realizing our suggestion, operators of the output test process will find their work easier. An unwritten benefit, however one that cannot be overseen, is also benefit for the customer and that is protection of the customer from receiving incompatible pieces. 


\section{ACKNOWLEDGMENT}

The authors would like to thank Agency KEGA for their support of the KEGA 011TU Z-4/2017 project „Integration of progressive information technologies and soft-skills in education programs focusing on management of production processes". This article was created as part of the project.

\section{REFERENCES}

[1] J. Banhard et al., Cellular Metals and Metal Foaming Technology. Bremen: MIT-Verlag, 2001.

[2] L'. Boledovič. (2007). CEZ (OEE) [Online]. Available: http://www.ipaslovakia.sk/sk/ipa-slovnik/cez-oee

[3] H. Čierna, E. Sujová and M. Ťavodová, Vybrané aspekty manažmentu pre technikov. Zvolen: TU Zvolen, FEVT, 2015.

[4] T. Dekýš, "Návrh zefektívnenia postupu výstupnej kontroly odliatkov hláv valcov $v$ spoločnosti Nemak slovakia s. r. o.", Bachelors thesis, Fakulta environmentálnej a výrobnej techniky, Technická univerzita vo Zvolene, Zvolen, 2016.
[5] Kočiš et al., Vyhne '12: Produktivní řizení slévárny. Brno-Trnitá: Česká slévarenská společnost, 2012.

[6] S. Kołodziej, E.W. Maruszewska. Economical effectiveness and social objectives in corporate social reports a survey among Polish publicly traded companies.15th International Multidisciplinary Scientific GeoConference SGEM2015 Conference Proceedings, DOI: 10.5593/ SGEMSOCIAL2015/B22/S6.021

[7] L'. Simanová, "Selected concepts and methods of quality assurance and improvement of processes and their exploitation in process control", in Proc. of Business Economics and management 2013, Technical University in Zvolen, Zvolen, Slovak Republic, 2013, pp. 309315.

[8] H. Yamagata, The Science and Technology of materials in automotive engines. Cambridge: CRC Press, 2003.

Erika Sujová, MSc., PhD., assoc. prof. Helena Čierna, MSc., PhD.

Technical University in Zvolen

Faculty of Environmental and Manufacturing Technology

Department of Manufacturing Technology

and Quality Management

Študetská 26, 960 53, Zvolen, SLOVAK REPUBLIC

e-mail: erika.sujova@tuzvo.sk,

cierna@tuzvo.sk 